\title{
MAKING UP THE ISSUE: THE JUDGES' ROLE IN FORMULATING ACTIONS IN THE CROWN COLONY PERIOD - PHARAZYN V SMITH (1844)
}

\section{Shaunnagh Dorsett*}

\begin{abstract}
This article considers one of the key procedural innovations of the first Supreme Court rules - the making up of the issue - through the lens of the Supreme Court decision in Pharazyn v Smith (1844). Making up the issue referred to the process whereby pleadings were drafted in conference with the judge hearing the case. This contrasted with the English system of the time of a series of written exchanges between parties designed to identify the disputed issues of fact and law, and in which the role of the judge was essentially a passive one. Through Pharazyn v Smith we can see one of the ways in which judges sought to modify English laws to the circumstances of the colony, as well as the judges' role in shaping litigation, and hence law, in the infant colony.
\end{abstract}

'God save thee, ancient Mariner!

From the fiends, that plague thee thus! -

Why look'st thou so?' - With my cross-bow

I shot the ALBATROSS. ${ }^{1}$

\section{INTRODUCTION}

On 24 May 1841 the Barque "Jane" arrived in Wellington. ${ }^{2}$ By all contemporary accounts it had been an uncomfortable, unhygienic and even dangerous voyage. There were insufficient supplies,

* Associate Professor, Faculty of Law, University of Technology, Sydney and member of the New Zealand Lost Cases project. My particular thanks to Stuart Anderson, Megan Simpson and Damen Ward, as well as Sam Richie and Phoebe Lindsley. The usual disclaimer applies. This case was recovered by the Lost Cases project, which is funded by the New Zealand Law Foundation. All online citations were correct at time of writing.

1 Samuel Taylor Coleridge "The Rime of the Ancient Mariner" first published in William Wordsworth (ed) Lyrical Ballads, with a few Other Poems (TN Longman \& O Rees, London, 1798).

2 For notice of her arrival see New Zealand Gazette and Wellington Spectator (Wellington, 29 May 1841) at 2 . 
the passengers quarrelled, and the boat leaked. At one stage it seemed the "Jane" might not complete the journey. Repairs and provisions were ordered in Rio de Janeiro, and in order to support the financing a bottomry bond (a form of security) was raised, supported by collateral security provided by a number of the cabin passengers, including our plaintiff, Charles Pharazyn, the Captain of the "Jane", Willam Stobo, and the attractive widow Jones. ${ }^{3}$ However, on arrival at Wellington the cabin passengers were unable to reclaim their securities: land orders; money orders; bills of lading; and bills of exchange. Pharazyn, for one, was penniless. Their attempts to recover these securities, or damages in lieu, resulted in a series of actions, of which Pharazyn $v$ Smith was one. ${ }^{4}$

This article is not, however, primarily a tale of hypothecations and bottomry bonds, although they will make an appearance. Rather, the importance of Pharazyn is that it allows us to shine a light on the functioning of the courts in the early colony and, in particular, on the court procedure which shaped the course of legal proceedings. When compared with the decisions examined by Damen Ward and David V Williams in this volume, Pharazyn may not seem to a be a case on reception of laws. Disallowance of colonial ordinances and the cut-off dates for Imperial legislation are the more traditional ground of reception of laws matters. However, the question of how procedure was modified in an infant colony is also crucial to our understanding of how the English legal system was received and adapted.

3 In his diary of the voyage, Pharazyn describes Mrs Jones as "a young widow of pleasing manners and appearance": Charles Pharazyn "Diary of Charles Johnson Pharazyn from London to New Zealand and the Journal of Waitarangi Sheep Station 1840-1850" Alexander Turnbull Library, Wellington (ATL), qMS1774, 5 December 1841 at 6 . Another passenger, Mary Frederica, daughter of the naturalist William Swainson, also wrote a diary during the voyage, as well as letters to her grandmother in England: Mary Frederica Marshall "Journal of a Voyage to New Zealand in the Barque Jane", 1840-1841, ATL, qMS-1336; Mary Frederica Marshall, "Letters of Mary Frederica Marshall to her Grandparents in England", 1840-1854, ATL, qMS-1337-1339.

4 For trover actions relating to the securities see Jones $v$ Smith, Supreme Court Wellington, 2 April 1844 per Chapman J, reported in the New Zealand Gazette and Wellington Spectator (Wellington, 17 April 1844) at 3; Stobo v Smith, SC Wellington, 3 April 1844 per Chapman J, and Pharazyn v Smith, SC Wellington, 4 April 1844 per Chapman J, both reported in the New Zealand Gazette and Wellington Spectator (Wellington, 24 April 1844) at 3 [Pharazyn $v$ Smith I]. The application in all three cases for rules nisi to show cause why judgment should not be arrested was granted by Chapman $\mathrm{J}$ at a motions hearing conducted on 22 April 1844, judgment rendered on 25 April 1844, reported in New Zealand Gazette and Wellington Spectator (Wellington, 15 May 1844) at 3 [Pharazyn rule nisi]; Pharazyn v Smith, SC Wellington 10 May 1844 per Chapman J, reported in New Zealand Gazette and Wellington Spectator (Wellington, 22 May 1844) at 3-4 (hearing to show cause) [Pharazyn v Smith II]. For Pharazyn I see HS Chapman "Notebook entitled 'Civil Trials No.1'", Hocken Library Dunedin (HL), 1844, MS-0411/002 at 83-93 ["Notebook: Civil Trials 1"], continued in HS Chapman "Notebook entitled 'Civil Trials No. 2'", 1844, HL, Ms-0411/003 at 212 [Notebook: "Civil Trials 2"]; for Pharazyn rule nisi and Pharazyn II see HS Chapman "Notebook entitled "Supreme Court: Sittings in Banco; motions, arguments \& judgments"', 1844, HL, MS-0411/014 at 50-102 ["Notebook: Sittings in Banco"]. Also arising from the voyage of the Jane include Stobo $v$ Swainson, SC Wellington, 3 October 1843 per Martin CJ, reported in New Zealand Gazette and Wellington Spectator (Wellington, 21 October 1844) at 2-3 (action on a guarantee). 
In 1843, Martin, with the advice of the Attorney-General, Swainson, and of Outhwaite, first the Registrar of the Supreme Court, drafted rules which he argued were suited to the circumstances of the infant colony. ${ }^{5}$ In a number of respects these rules substantially modified, or even abandoned, English procedure. The importance of procedure is often overlooked by colonial legal historians in favour of the emergence of principles or doctrine. ${ }^{6}$ Yet as Pharazyn reminds us, procedure was at the heart of the legal system, and it dictated the shape of the arguments which could be made by plaintiffs and, hence, the structure and development of the laws of the colony. This is particularly so of the specific procedural question investigated in this article: the role of the judge in formulating actions and determining what issues would be brought before the court in the Crown colony period (known as making up the issue, or making up the record).

Pharazyn was arguably the most complex civil case yet heard by the Supreme Court in its thirteen months of business. It involved the consideration of three jurisdictions (admiralty, common law and equity), five of the seven barristers in Wellington at the time appeared, ${ }^{7}$ and it was one of the first civil matters that Chapman $\mathbf{J}$ had heard in his, to that point, exceedingly brief judicial career. Pharazyn I was one of three cases before the Supreme Court in which the plaintiffs sought return of their securities. They were followed by a successful rules nisi application, and then a further hearing at which the plaintiffs were required to show cause why the original judgment should not be arrested (Pharazyn II).

Part I looks at what is meant by making up the issue, how this happened under the 1843 and 1844 Rules of the Supreme Court, ${ }^{8}$ and in what ways this process differed from English procedure

5 Rules and Orders Touching the Practice of the Supreme \& County Courts of New Zealand, (Government Press, Auckland, 1843) enclosure in Shortland to Colonial Secretary, Despatch No 56, 16 June 1843, The National Archives London (TNA), CO209/21: 272 [1843 Rules]. See also Martin's request to Shortland, 15 June 1843, that they be transmitted to London: Archives New Zealand (ANZ), AGCO 8335 IA1/23, 43/1273. For Martin's acknowledgement of the advice and help of Swainson and Outhwaite see William Martin "Report on the establishment of courts and the general regulation of the judicial establishment", 12 June 1843, enclosure in Shortland to Stanley, Despatch No 29 of 1843, 8 May 1843, ANZ, ACHK 16585, G30/3 at 446 ("Report"). Although the date of the enclosure post-dates that of the despatch, these dates are correct for each document.

6 Two exceptions to this in the context of New Zealand history are PA Cornford "The Administration of Justice In New Zealand 1841-1846; Part I: The Fisher Period" (1970) 4 NZULR 18; PA Cornford "The Administration of Justice In New Zealand; Part II: The Swainson Period" (1970) 4 NZULR 120; and Edwin Fletcher "A Rational Experiment: The Bringing of English Law to New Zealand" (MA Thesis, University of Auckland, 1998).

7 Richard Hanson (later Chief Justice of South Australia) and Hugh Ross appeared for the plaintiffs (Jones, Stobo, Pharazyn); Robert Hart and Arthur Holroyd appeared for Smith, and Daniel Wakefield (the brother of Edward Gibbon Wakefield) replaced Holroyd at the rules nisi hearing. The barristers not to appear were John King and Alfred de Bathe Brandon.

8 An Ordinance to confirm certain Rules, Forms, and Table of Fees touching the Practice of the Supreme Court 18448 Vict No 1. 
at the time. There are few cases in the colonial period in which Supreme Court procedure can be seen in action. Pharazyn is, in this way, almost unique. However, in order to understand how the process of making up the issue became so important in this decision it is necessary to unpick the difficulties which arose in bringing this action to court. Part II, therefore, steps backward and looks at the voyage of the "Jane", or the "unsavoury Jane" as she became nicknamed, between London and Port Nicholson. This part looks at how the Master, Stobo, entered into the bottomry bond which underlay subsequent litigation. Part III looks at the trial in Pharazyn and the attempt by the cabin passengers to obtain damages for the loss of their securities by bringing a common law action in trover. It describes why a simple Admiralty case became a problematic action at common law, and in particular the difficulties caused by the awkward translation of admiralty matters into common law doctrine. ${ }^{9}$ Part IV considers the rules nisi hearing and the subsequent arguments to show cause why judgment should not be arrested. ${ }^{10}$ The role of the Judge in making up the issue, and his alleged failure, is at the heart of Pharazyn II. Key issues were not properly raised at trial. Should the Judge have alerted counsel? Was failure to do so the "Court's fault" - the result of Martin's procedures? In a colony with simplified and uniform procedures what role did a judge take in directing litigation?

\section{MAKING UP THE ISSUE}

The practice of "making up the issue", by which the pleadings (and hence central issues) were drafted before the judge, was a significant departure from English practice and was one of the key procedural innovations in the new colony. It was central to Martin's 1843 Rules and his attempt to provide for a simplified procedure and pleading which was appropriate for the infant colony. It remained a central plank of the 1844 Rules. ${ }^{11}$ Under r 26 of the 1843 Rules, all parties were required to appear before the judge, who: ${ }^{12}$

... shall proceed by examination of the parties or their Solicitors, to elicit the point in issue. He shall then reduce into writing and enter into a book, to be called the Issue Book, the material statements of the

9 Admiralty and common law were separate jurisdictions with separate court structures. In England as a result of the Judicature Acts, admiralty became one division of the High Court: see Supreme Court of Judicature Act $187336 \& 37$ Vict c 66, ss 3 and 4 .

10 A rule nisi was an order to show cause. Hence it was a request to the court by the defendant, supported by affidavit, and generally heard in chambers, to require the plaintiffs to show cause why the judgment should not be made absolute. It was followed by a full show cause hearing.

11 The 1844 Rules were drafted by Martin CJ and Chapman J, although in fact they differed little from Martin CJ's 1843 Rules. In a letter to his father Chapman notes that while in Auckland awaiting the Government Brig to take him to Wellington he stayed with Martin and they had "plenty of work to do revising the Supreme Court Act and making new Rules of Court suitable for the new circumstances of the colony": HS Chapman to H Chapman "Letters", ATL, qMS-0418, letter dated 20 January 1844 at 48 . The Rules also applied, with some minor modifications, to the County Court.

12 Martin "Report", above n 5, at 443. 
respective parties, making notice of any defence which would be available by the law of England as administered by courts either of law or equity; which entry shall be signed by them.

It was further provided that the general issue could not be pleaded (r 27). Rule 26 reappeared in substance, but more detail, in $\mathrm{r} 28$ of the 1844 Rules, although the restriction on the general issue had been removed. Such a restriction was presumably not necessary in a system where the pleadings were made up before the judge. By then the "Issue Book" had been renamed the "Record Book" and, as well as issue and defence, particulars of any set-off were required to be specified. In a report to the Colonial Office on what might constitute a sufficient establishment of the machinery of the law and regulation of the judicial establishment in 1843, Martin devoted some portion to specifically addressing his choice to place the making up of the issue in the hands of the judges, and to defending his abandonment of English procedure in this regard. He stated (and it is worth quoting in some detail): ${ }^{13}$

... of the abstract merits or the demerits of the English system it is quite unnecessary to speak. It will be remembered however that lawyers of the highest name, both practical and speculative, have strongly recommended the adoption even in England itself of one widely different - They have thought it likely to conduce to the simplicity and promptness of legal proceedings that the whole business of pleading, the ascertaining the point in issue between the parties - should not be left to be transacted between the parties or their agents, without any control beyond such as may arise from the technical rules of pleading, but should rather be disposed of by a judicial officer having no interest in complication verboseness or delay.

He claimed that therefore his "abandonment of the English system in that point was a matter not of rashness or of speculative experiment but of necessity". ${ }^{14}$ In 1854 the Reports of the Commissioners into Procedure (authored by Martin CJ and Chapman J) confirmed that "the very artificial system of pleading which prevails in the Common Law Courts of England, and the prolix proceedings by bill and answer, employed in the English Courts of Equity, could not possibly [have been] adopted here, without creating such delay and expense as to amount to a denial or defeating of justice". ${ }^{15}$ Martin was, of course, not the only colonial judge to draw up simplified procedures for use in a new colony. Francis Forbes' 1825 rules for the Supreme Court of New South Wales

13 Ibid, at 443-444. See also Cornford "Administration of Justice II", above n 6, at 136; Fletcher "A Rational Experiment", above n 6.

14 Martin "Report", ibid, at 444-445.

15 [William Martin and Henry Samuel Chapman] Reports of the Commissioners appointed by His Excellency the Governor-in-Chief to Inquire and Report into a System of Practice and Procedure suited to the Supreme Court of New Zealand (Williamson \& Wilson, Auckland, 1854) at 3-4 (Reports of the Commissioners). For the limited role of Stephen $\mathrm{J}$ in this procedural reform see William Martin "Martin Papers 1851", ATL, MSPapers-1743, Martin to Chapman, letter dated 23 June 1851, unpaginated. 
remained in place, with some amendments, until 1840. ${ }^{16}$ Martin's Rules followed a similar schema to those of Forbes: they were a short set of rules which specifically changed certain aspects of English procedure or pleading, in all other respects leaving English practice in place as far as consistent with "circumstances of the colony". ${ }^{17}$ Both initiated proceedings by way of a simple summons or notice. ${ }^{18}$ There is, however, no suggestion in Forbes' rules that judges make up the issue.

In 1851, the matter of who should be responsible for pleadings was raised by the English Common Law Commissioners. Should pleadings be settled by a public officer of the court specially appointed for that purpose (presumably not necessarily a judge)? The suggestion was dismissed. Such a procedure would be "highly inconvenient". ${ }^{19}$ It would simply add a layer of complexity to suits, requiring specifically appointed officers, and not eliminating the need for special pleaders to help draw up the issue. Rather, true reforms would "do away with technical and formal arrangements and made the mode of objection to uncertainty, duplicity, or argumentativeness as direct and as little dilatory and expensive as possible". ${ }^{20}$

Overall, however, direct pleading and procedure was exactly what Martin, first alone, and then with Chapman, wanted to achieve. Chapman was equally committed to legal simplification, stating in 1844 that he intended to make his reputation as "a colonial judge and indirectly as a legislator and law simplifier". He claimed to have "already done one or two things that would have delighted $\mathrm{B}[$ entham] had he been alive. He noted that "[1]ittle did he [Benthan] think that his spirit would animate the procedure of a country, which, when he died was only the abode of savages". ${ }^{21}$ For Martin and Chapman, making up the issue was only one facet of simplified and uniform rules of procedure appropriate for a new colony with one superior court exercising two jurisdictions. ${ }^{22}$ The

16 Rules dated 22 June 1825, but probably updated in early 1826. For the first draft see the Australian (Sydney, 13 January 1825) at 1. For the 1825 version see Sydney Gazette and New South Wales Advertiser (Sydney, 23 June 1825) at 1; The 1826 version is printed in Robert Howe and Ralph Mansfield Australian Almanack for the Year of Our Lord 1827 (Howe and Mansfield, Sydney, 1827). Howe printed updates annually until 1833.

17 Forbes Rules, ibid, r I; 1843 Rules, above n 5, unnumbered statement, located after r 72; 1844 Rules, above n 8 , unnumbered statement, located after $\mathrm{r} 74$.

18 Forbes Rules, ibid, r 10; 1843 Rules, ibid, r 10; 1844 Rules, ibid, r 12.

19 First Report of Her Majesty's Commissioners for Inquiring into Process, Practice, and System of Pleading in the Superior Courts of the Common Law (Eyre \& Spottiswoode, London, 1851) at 21.

20 Ibid.

21 Chapman "Letters", above n 11, letter dated 4 June 1844 at 103. On Chapman's involvement with Bentham see Shaunnagh Dorsett "Sworn on the Dirt of Graves: Sovereignty, Jurisdiction and the Judicial Abrogation of 'Barbarous' Customs in New Zealand in the 1840s" (2009) 30 The Journal of Legal History 175.

22 By contrast, in developing the rules of the Supreme Court of New South Wales, Forbes CJ did not look to provide uniform rules for a court with multiple jurisdiction, providing specifically that "the Proceedings of 
advantage of making up the issue before the judge, according to Martin and Chapman, was that the "Court made itself responsible for the form of the pleadings" removing all devices which promote "expense and delay. ... Secondly, by adopting specific allegations, commencing with the declaration, and omitting all fictions, the Court and the parties were informed at once of the real and substantive question in dispute between the parties, barred of every averment not necessary to its merits; and the expense of the trial was greatly diminished". ${ }^{23}$ In particular, specific averment "at the very commencement (ie in the declaration itself) and throughout the pleadings" was required "in all actions whatsoever". ${ }^{24}$ Making up the issue was to replace the process in England at the time whereby pleadings took place by way of a series of (often lengthy) written exchanges between the parties and in which, as Polden points out, the judge took "an essentially passive part". ${ }^{25}$

The procedure whereby the issue was made up before the judge might, through modern eyes, be viewed as early "case management". However, just as for the English Commissioners some years later in 1851, simplified procedures and pleading did not obviate the need for "proper" pleading. It appears that making up the issue did not as such remove the stages of the process of pleading declaration; plea; replication; rejoinder - but rather they no longer took place through a (sometimes protracted) exchange of documents. In fact, Martin's initial removal of the right to plead the general issue might indicate that he was at least notionally an adherent of "special pleading" which held in English practice at the time, and of which Henry Stephen, by coincidence the brother of James Stephen, Permanent Under-Secretary to the Colonial Office, was the doyen. ${ }^{26}$ The ultimate purpose of special pleading was exactly that which Martin wished to achieve through the judge's involvement in making up the issue: an economical system which pared down the issues, discriminating carefully between law and fact, and making for short trials. ${ }^{27}$ Special pleading, however, was something of an art. It was highly technical, few outside the profession understood it, and within the profession it had both adherents and critics. Its particular vice was fictions - for example the famous John Doe - and Martin's emphatic rejection of fictions suggests that he himself was not particularly in favour of special pleading. Martin's choice of making up the issue more

the said Supreme Court, within its several and respective Jurisdictions, as aforesaid, be commenced and continued in distinct and separate form": 1825 Rules, above n 16, r II.

23 [Martin, Chapman] Report of the Commissioners, above n 15, at 4-5.

24 Ibid, at 5

25 Patrick Polden "The Courts of Law" in William Cornish and others The Oxford History of the Laws of England (Oxford University Press, Oxford, 2010) vol 11 at 581.

26 Henry John Stephen A Treatise on the Principles of Pleading in Civil Actions (4th ed, Saunders and Benning, London, 1838). On this see work see Polden, ibid, at 581.

27 Polden, ibid. 
likely reflected the reality of a new colony with a limited legal profession, its members not always exhibiting the highest skills, and a smaller, easily manageable judicial load. ${ }^{28}$

Intriguingly, in his justification for "abandoning" English procedure, Martin stated that he had "less misgiving than might otherwise be felt as I remembered that in the Colonial Office its main principle had been recommended to me by the highest authority". ${ }^{29}$ Regardless, of who this higher authority might have been, the Colonial Office had previously recognized the need for appropriate and simple procedure in new colonies. In 1824 by Order in Council Francis Forbes was instructed to draft rules which were "plain, simple and compendious", while "avoiding all unnecessary dilatory or vexatious forms of proceeding". Nevertheless, they were to adopt the "appropriate Language and technical terms of the Law of England". ${ }^{30}$ Whether or not specific suggestions were made to Martin that the judges should formulate the issue is unknown. This innovation may have come from the practice and procedure of one of the jurisdictions to which Martin noted he was indebted in drafting his 1843 Rules. ${ }^{31}$ In their later substantial report into procedure in 1854, Chapman and Martin were not in favour of rejecting English pleading. They were much influenced by both recent English reforms and those of the Field Code in New York, and looked to retain the fundamentals of English pleading in order to elicit the legal issues or facts in question, albeit simplified and stripped of all fictions.

In his 1843 Report on the Judicial Establishment, Martin recognised that an infant procedural system, particularly one in which the judges made up the issue, required a certain calibre of capable judge. He wrote that where the judge makes up the record certain qualities are required in such an officer. He must set himself against "every case of unnecessary expense or delay", and for that reason must "possess such a degree of practical familiarity with the law as to be able to readily discern the legal question raised before him, to separate that which contributes to the case from that which is merely evidence in support of the case, and clearly to elicit the special points in issue between the parties". ${ }^{32}$ Martin recognised, therefore, that in such a system much was left in the

28 Its also unlikely that Chapman was an adherent of special pleading as the severest critics of this system were Bentham and his followers: ibid, at 582.

29 Martin "Report", above n 5, at 444.

30 Order in Council, 19 October 1824, enclosure in Bathurst to Brisbane, Despatch No. 50 (24 December 1824), Historical Records of Australia: Series I (Committee of the Commonwealth Parliament, Sydney, 1914-1925) vol XI at 426-429. Forbes had, however, substantively drafted the rules prior to the authorisation by Order in Council arriving: see CH Currey Sir Francis Forbes (Angus \& Robertson, Sydney, 1968) at 109.

31 Martin specifically noted that in drafting the 1843 rules he was much indebted to the example of the Cape, Ceylon, and to the practice of Western Australia and New South Wales: Martin "Report", above n5, at 446.

32 Ibid, at 448. 
hands of the judge and that the judge was responsible to some extent for setting litigation off on the right track.

Making up the issue caused little controversy it seems until Pharazyn $v$ Smith. ${ }^{33}$ When faced, however, with the complex litigation in that case, crossing as it did several jurisdictions, the question of who was responsible for making up the issue, and whether the colony might have been better served by a system of pleading more cumbersome, but ultimately perhaps more likely to elicit the legal issues, came to the fore. In order to understand why Pharazyn was so complex, and raised these matters, it is necessary to return to the voyage of the "Jane" and the granting of the troublesome bottomry bond which underlay all subsequent litigation.

\section{THE BOTTOMRY BOND AND THE VOYAGE OF THE 'UNSA VOURY JANE'}

The "Jane" left England on 28 November 1840. She was a privately owned by a Mr Walkinshaw of Glasgow, under the command of Captain Stobo. From the outset it was clear that, at least in the opinion of the "Gentleman Cabin Passengers" that the boat was crowded and under-vitualled; the provisions were, according to Pharazyn "a miserable take in altogether". ${ }^{34}$ Things went badly from the beginning. By day four of the voyage the weather and crowding were taking effect: five of the twelve pigs were smothered due to crowding, leaving the passengers further under-provisioned. ${ }^{35}$ By the sixth, a hurricane had hit. Almost all the passengers were ill, and Pharazyn described the conditions as bad. He wrote of the "miserable inconveniences of the ship ... dirt and filth the order of the day". Insufficiently lashed cargo escaped, the galley fire was inadequate for the needs of the 80 on board and a "want of space" made life uncomfortable. He praised the Captain's seamanship, but complained that the owner "takes us all in very bad". ${ }^{36}$ After a short break at Port Preya de Iago, Cape de Verdes, where additional provisions were taken on board, the ship reached Rio de Janeiro on 2 February, intending to take on water and depart on 6 February.

33 Martin refers to the practice being tested over the course of a year (mid-1842 to mid-1843) through around 160 cases in Wellington and Auckland: ibid, at 444. This figure most likely refers to both Supreme Court and County Court cases. By 17 June 1843 only approximately 37 civil cases had proceeded through the Supreme Court: see New Zealand Lost Cases database <www.victoria.ac.nz/law/nzlostcases>. In support of these smaller numbers note that in 1845 Chapman wrote to his father of the relatively small caseload of the Supreme Court, particularly in Auckland. Chapman believed one judge would suffice for the entire colony: see, for example, Chapman "Letters", above n 11, letter dated at 1 July 1846 at 230, and letter dated 30 September 1845 at 247.

34 Pharazyn "Diary", above n 3, 1 November 1840 at 3. This opinion was confirmed by Robert Hesketh, the Consul at Rio de Janeiro: Hesketh to Hobson (5 March 1841) enclosure in Hesketh to Palmerson (13 March 1841) TNA, FO13/173, fol 95.

35 "Diary", ibid, 2 December 1840 at 3.

36 Ibid, 6, 7 and 8 November 1840 at 6-7. 
It is here that matters came to a head. Before the ship could leave, complaints were raised with the British Consul by the intermediate and steerage passengers as to the state of the ship and provisions. Presumably if the voyage had been uncomfortable for cabin passengers, matters had been significantly worse in steerage. The British Consul at the time was Robert Hesketh. ${ }^{37}$ Hesketh ordered a survey of the ship to be made, which revealed both that the decks leaked and that the longboat was, and had been from the outset of the voyage, unseaworthy. ${ }^{38}$ According to Mary Frederica, daughter of the naturalist William Swainson, who was emigrating on the "Jane", the inspecting officers said that they had "never seen a vessel in so dirty a condition". 39

Once Hesketh had deemed the refit and re-provision necessary the problem was one of how to pay for this. The money ( $£ 543$ ) was raised on the $5^{\text {th }}$ March 1841 , secured by a bottomry bond at a 100 per cent premium, ${ }^{40}$ the lender being Naylor Bros \& Co, a British commercial trading firm, acting as the leader of a consortium of eight traders. ${ }^{41}$ The amount could have been higher: two of the cabin passengers, Mr St Aubyn and Mr McDonnell, requested that an additional $£ 300$ of provisions be laid in on top of those ordered by Hesketh, and that the cargo be landed and sold to pay for them. ${ }^{42}$ Hesketh rejected this request after a written protest by many of the remaining cabin passengers. ${ }^{43}$

37 On Hesketh see Ian Sargen Our Men in Brazil: The Hesketh Brothers Abroad (Scotforth Books, Lancaster, 2009).

38 The role of the consul was ill-defined. Until 1825 most consul were British traders, often chosen because they were the leaders of local commercial communities. Most served in seaports, and hence their main concern was maritime affairs, particularly the regulation and protection of seamen and British ships: DCM Platt The Cinderella Service: British Consuls Since 1825 (Longman, London, 1971) at 6. In 1825, under Foreign Secretary George Canning, legislative reforms were made to the salaries and payments made to British Consuls. One of the main thrusts of the reform was to use consuls to expand British trade, and in effect act as trading agents, but this was short lived, and by 1831 the traditional view had been reinstated that "first, and overwhelmingly the most important, function of a consul was maritime": Platt Cinderella Service, ibid, at 18. The Act failed to describe the role and powers of consuls fully, although the list of fees that could be charged for services does give some idea of what these may have been. The fee for a bottomry or arbitration bond was US \$2, while that for noting a protest was \$1: An Act to regulate the Payment of Salaries and Allowances to British Consuls 18256 Geo IV c 87 (UK), s IV and Table B.

39 Marshall "Diary", above n 3, 8 January 1842 at 22.

40 Bottomry Bond entered into 5 March 1841 at Rio de Janiero. The bond can be found in the State Records Office New South Wales (SRNSW), Case Papers Vice-Admiralty Court New South Wales, NRS 14493 [4/7604], Case Papers for the Barque Jane.

41 Hesketh to Hobson, above n 34, fol 95. It seems that none of the traders were willing to grant a bond, and eight of them only reluctantly agreed to do so as a kind of consortium after the intervention of Hesketh.

42 Pharazyn, "Diary", above n 3, 27 February 1841 at 14.

43 Swainson, Pharazyn, John Selby, JG Western and Jones: ibid, 1 and 3 March 1841 at 14. 
As a matter of admiralty law, the master of a ship traditionally had the power to hypothecate the ship and or its cargo in order to raise money to refit and re-provision during the voyage. ${ }^{44}$ This was usually achieved by way of bottomry bond, which allowed ships to be "pledged" in order to raise money. A contract of bottomry is generally considered a form of hypothecation, although it is perhaps more properly a lien. Hypothecation consists in the power to cause something to be sold. It is known as a bottomry bond as it is pledged on the keel or bottom of the ship. ${ }^{45}$ The key feature of a bottomry bond is that all risk lies with the lender. For the bond to be redeemable the ship must perform a voyage and arrive safely. If the ship is lost, the security is gone. The offset for the risk is that the lender may charge whatever interest as may be agreed upon, however otherwise usurious. ${ }^{46}$ The key difference between a hypothecation and a common law mortgage is that neither possession nor title are transferred by hypothecation. Hypothecation indirectly binds the owners but does not render them liable to be sued either in common law or admiralty, although it may be possible, depending on the terms of the bond, to proceed against the shippers after ship and cargo are exhausted. ${ }^{47}$ In the case of the bond on the "Jane", the Master, Stobo, also bound himself and his heirs personally. ${ }^{48}$ For a bottomry bond by a master to be valid it must have been that the repairs were necessary for safety or to effectuate the objects of the voyage, the owner be not present and that his funds were not available at that place, and that it occur at a place where the Master has no other means of repairing the ship. ${ }^{49}$

Naylors, however, did not consider the bond alone adequate security. The traders in Rio were aware of the possible problems that might be faced in enforcing a bottomry bond in the new colony. ${ }^{50}$. Several of the cabin passengers, who became the litigants subsequently in Wellington, were therefore forced to put up collateral security. The security was apparently raised by subscription through a number of the cabin passengers pledging their property. ${ }^{51}$ It was not that unusual for collateral security to be given with bottomry bonds, the most common being a bill of

44 The Ship Gratitudine (1801) 3 C Rob 240, 165 ER 450 (Instance Court); The Lord Cochrane (1844) 2 W Robb 320, 166 ER 775 (Instance Court); In re The Hero (1817) 2 Dods 139, 165 ER 1440 (Instance Court).

45 If money is borrowed against the security of the cargo only this is known as respondentia.

46 Usury is the charging of interest on loans. In England, usury laws prevented the charging of excessive interest rates on loans. For a discussion of usury in a colonial context see MacDonald $v$ Levy Supreme Court of New South Wales, 8 March, 1833 per Forbes CJ, Dowling and Burton JJ, available at <www.law.mq.edu.au/nswsc>.

47 The Jacob (1802) 4 C Robb 245, 165 ER 600 (Instance Court).

48 Bottomry bond, above $\mathrm{n} 40$.

49 Rhadamanthe (1813) 1 Dods 201, 165 E.R. 1283 (Instance Court). The Master also has power to sell cargo for this purpose.

50 Hesketh to Hobson, above n 34, fol 96.

51 Pharazyn, "Diary", above n 3, 3 March 1841 at 15. 
exchange. In such cases, the bill of exchange was usually presented first, and the bottomry bond only if it was believed that the bill would not be paid. ${ }^{52}$ Collateral security was provided by Pharazyn, Swainson, Mrs Jones and Captain Stobo himself. ${ }^{53}$

Despite the re-provisioning, re-corking and new longboat, it does not seem that the remainder of the voyage was notably better: weather was inclement; the food remained bad (the sheep and poultry died); and relations between the cabin passengers deteriorated significantly. While they had not been good before Rio, afterwards they took a turn for the worse. Pharazyn described them as "splitting into camps", ${ }^{54}$ and noted that there was "slander abroad at Mrs Jones's expense" ${ }^{55} \mathrm{He}$ himself alleged in his diary that Mrs Jones had entered into a liaison with the Captain, ${ }^{56}$ while Mary Frederica noted that a sentinel had to be stationed on deck as Mr McDonnell had threatened to throw Pharazyn overboard. ${ }^{57}$ It was even alleged that at some stage the Captain and certain passengers were placed on good behaviour bonds, ${ }^{58}$ although later Stobo himself denied this under cross-examination. ${ }^{59}$ Perhaps all of this can be explained by Mary Frederica's diary entry for 18 May in which she records that a Mr St Aubyn finally managed to shoot an albatross. ${ }^{60}$ Young Mr St Aubyn was apparently not a lover of poetry.

On arrival, however, Pharazyn and the others were unable to recover their securities. They ended up in the hands of Mr John Smith, Manager of the Wellington Branch of the Union Bank of Australasia, agent for Naylor Bros \& Co, who refused to release them. ${ }^{61}$ Pharazyn noted in his diary that "owing to the manager of the bank refusing to give up my securities pledged to Naylor \& Co at

52 William Tarn Prichard A Digest of the Law and Practice of the High Court of Admiralty (2nd ed, Stevens and Sons, London, 1865) vol 2 at 634-635.

53 Security may also have been given by a Mr Fry, although he does not subsequently appear in any accounts or proceedings: Pharazyn, "Diary", above n 3, 3 March 1841 at 15.

54 Ibid, 21 December 1840 at 8.

55 Ibid, 4 January 1841 at 9.

56 Ibid, 15 February 1841 at 13.

57 Marshall "Diary", above n 3, 15 April 1841 at 36. Thomas McDonnell was given the honorary appointment of additional British Resident in 1835 but resigned in 1836. After some time in England, he returned to New Zealand on the "Jane".

58 As reported by Sutton, a passenger, and witness in Stobo v Swainson, above n 4. According to Sutton, McDonnell was the "referee" for the passengers, and Pharazyn for the Captain.

59 Chapman "Notebook: Civil Trials 1 ", above n 4, at 86. Rather, the bond was that the passengers should have the scale of provisions to which the surveyors in Rio de Janeiro had stated they were entitled.

60 Marshall, "Diary", above n 3, 18 May 1841 at 42. For other incidents of wounding albatross see entry for 13 April 1841 at 36. Apparently St Aubyn determined to stuff the carcass: 18 Mary 1841 at 42-43.

61 On the Union Bank of Australasia see SJ Butlin Australia and New Zealand Bank (Longmans, London, 1961). 
Rio de Janeiro" he found himself "literally penniless". As a result, the family "took up their abode in a native built warrie on the kia warre warre road [sic]", of which the "floor and walls were neither air or water proof, [and in which] fleas and rats [were] innumerable". ${ }^{62}$ Thus, Monday 28 June found Pharazyn "behind the counter of a retail shop in Pipitea, not a whit better or so respectable looking as a Chandlers shop in some country village in England..." bemoaning that he had emigrated "16, 000 miles ... for the honor of being a Chandler shop keeper in New Zealand". 63

For Captain Stobo, on the other hand, the misery went on. He found himself facing a Wellington Bench of Magistrates in June, accused by Mr McDonnell of having "not furnished [the cabin passengers waiting to continue to Auckland] with provision, lights and attendance" since 29 May 1841. The matter was dismissed. ${ }^{64} \mathrm{He}$ was, however, successfully sued for damages for unpaid wages in the Water Police Court in Sydney in November of that year. ${ }^{65}$

\section{PHARAZYN V SMITH: ACTION FOR TROVER}

The three plaintiffs, Jones, Stobo and Pharazyn brought actions in trover. Trover was, and is, an action to recover damages from the defendant, here Mr John Smith, manager of the Wellington Branch of the Union Bank, for wrongfully infringing the plaintiff's right to possess goods, in this case the securities. They collectively sought $£ 1650$ damages. In trover only damages can be obtained. For return of the goods (in specie), detinue was the appropriate action. While the securities were physically present, having been given up to the plaintiff's solicitors (Hanson and Ross) in court, the action was presumably taken in trover because the plaintiffs sought higher damages than the actual value of the orders and merchandise. They had, after all, been without their securities for only a few weeks shy of three years, resulting in some hardship and in the specific case of the bill of lading, the goods to which it related had long been sold. In Pharazyn's case a significant issue was the valuation of his land orders, and the difference in their potential worth between arrival and trial. ${ }^{66}$

62 Pharazyn "Diary", above n 3, 11 June 1841 at 17. Pharazyn's "pigeon" Māori refers to living in a whare on the Kaiwharawhara Road.

63 Ibid, 28 June 1841 at 18 New Zealand Gazette and Wellington Spectator (Wellington 12 June 1841) at 2.

65 Clarrebutt \& Ors v Stobo Water Police Court Sydney, 19 October 1841, reported in Sydney Herald (Sydney, 22 October 1841) at 2; reported locally in the New Zealand Gazette and Wellington Spectator (Wellington, 3 November 1841) at 3; Due to Stobo being unable to pay, the crew also commenced actions in the Vice-Admiralty Court in Sydney, asking for, and obtaining, a warrant of arrest against the ship: Adamson \& Ors v Barque "Jane", Warrant, Case Papers for the Barque Jane, above n 39.

66 Chapman "Notebook: Civil Trials 2", above n 4, at 7 and 10. 
Many of the details of the trial in Pharazyn $v$ Smith, a trial which lasted approximately twelve hours, are unknown. ${ }^{67}$ In his notebook, Chapman J only records the evidence of the witnesses although he writes a full judgment for the later decision for request for an arrest and new trial. In the newspaper, Pharazyn receives short shrift. This is because the Gazette has already reported the first of the three cases to be heard, Jones $v$ Smith, in detail. We can, therefore, extrapolate what legal issues were raised from Jones, although we cannot be sure that Chapman's summing up and directions to the jury were identical. At the rules nisi hearing, Chapman chose Pharazyn to stand for all three on the grounds that "it contained all the others contained and something more. It was, in fact, the strongest in favour of the defendant". 68

The action was brought against Mr Smith because he was the Manager of the Union Bank of Australasia. The Manager was, under the terms of the bond, appointed to act as agent for Naylor Bros \& Co. The choice of Mr Smith (as well as presumably that of Mr James Sea, Manager of the Union Bank in Sydney, who subsequently acted for Naylors in that city) was that of Hesketh, the Consul in Rio. ${ }^{69}$ It appears not to have been a task Smith took on voluntarily. He was simply nominated by Hesketh. It appears that the securities were physically brought to Smith in a package by Stobo. ${ }^{70}$ The crucial clause of the agreement provided that securities would be returned on the happening of one of three things: ${ }^{71}$

(1) payment of the bond;

(2) loss of the ship; or

(3) Mr Smith being satisfied of the sufficiency of the value of the ship and the freight to discharge the bond.

The key event was the third of these possibilities. As the bond could not be paid, and the ship had arrived safely, the bond could only be discharged and the securities returned upon Mr Smith determining the value of the ship and cargo sufficient to discharge the bond. Thus, on the ship's arrival in Wellington Stobo and Pharazyn offered Mr Smith the ship and cargo, subject to seamen's wages, on the condition he give up the securities. Smith, however, appears to have been unclear whether he could enforce the bond in Wellington in the absence of a Court of Vice-Admiralty. The

67 Pharazyn $v$ Smith I, above $\mathrm{n} 4$.

68

Chapman Pharazyn rules nisi "Notebook: Sittings in Banco", above n 4, at 47.

69 Hesketh to Hobson, above n 34, at fol 96. Hesketh solicited Hobson's assistance, if necessary, for the Manager of the Union Bank of Australasia. Mr Smith is not personally named in the letter.

70 Pharazyn v Smith I, Evidence of William Stobo: Chapman "Notebook: Civil Trials 1", above n 4, at 84.

71 Jones $v$ Smith, above $\mathrm{n} 4$. We can only reconstruct this from the report of the judgment. While the actual bottomry bond is in the State Records Office of New South Wales, the subsidiary agreement with respect to the collateral securities does not appear to have survived. 
appropriate course to enforce a bottomry bond was to put the bond into suit in admiralty and request from the Instance Court a Decree of Appraisement and an order for sale. In contrast to the in personam jurisdiction of the common law, proceedings in Admiralty were in rem, in other words one arrested the ship and then proceeded against it. Smith's inability to arrest the "Jane" lead to the odd result that the primary security departed New Zealand, while Smith kept the collateral securities.

Hanson submitted for the plaintiffs that Smith ought to have enforced the bottomry bond and returned the securities. In particular, he had no right to refuse to enforce the bond but keep the collateral securities. Thus, the only question to be answered was whether Smith had done what he ought to have done under the terms of the collateral security. Hanson argued that the securities were not deposited so that Smith could retain them at his discretion, but that he was required to satisfy himself as to the value of the ship being sufficient, and then required to give them up. Unsurprisingly, Holroyd argued for the defendant that Smith was entitled to hold the securities until the bond was paid, or until there was proper means by which the defendant could ascertain the value. The only way that could have occurred was by putting the bond into suit in a court of viceadmiralty. ${ }^{72}$

In fact, Naylor Bros did try to put the bond into suit, but in Sydney, via their agent Mr Sea on the "Jane's" arrival in that city. ${ }^{73}$ Bottomry bonds could be enforced in any court of Vice-Admiralty, regardless of where the bond was made, or the ships destination on that voyage. In Wellington, in order to raise additional finance (largely to pay the seamen's wages), Stobo had advertised for, and obtained, a second bottomry bond. ${ }^{74}$ The "Jane" then left for Auckland, and from there to Sydney, arriving on 11 September. ${ }^{75}$ On hearing that the original bond was to be put into suit, Mr Jones, agent for Wade, the holder of the second bond, put that bond into suit. ${ }^{76}$ Naylors' obtained a decree

72 It was not just the alleged lack of vice-admiralty jurisdiction that was the problem. In 1841 there was no court in which Pharazyn could have commenced an action. Courts of Requests were instituted late in 1841, the first sitting in Wellington being 19 October 1841. However the Commissioners could only hear trover where the value was under £50: Ordinance to establish Courts of Requests 18414 Vict No 6, ss 3 and 4 . The Courts of Request were replaced in late 1841 by County Courts, which had an even lower threshold for civil matters of $£ 20$ : County Courts Ordinance 18415 Vict No 2, s 10.

73 Action Books, Vice-Admiralty Court of New South Wales, SRNSW, NRS 14497 [4/6674] at 5.

74 Stobo advertised for a party willing to grant a bond: see New Zealand Gazette and Wellington Spectator (Wellington, 12 June 1841) at 1. The bond holder was John Wade. John and George Wade (brothers) were merchants and agricultural shippers. The bond was signed on 3 August 1841 and raised £400 at 120 per cent: see Captain William Stobo to J Wade Esq, Bond, Case Papers for the Barque Jane, above n 40.

75 Sydney Herald (Sydney, 13 September 1841) at 2.

76 John Wade v The Barque Jane, Action Books, above n 73 at 5-6; John Wade v The Barque Jane, Entry of Action, Case Papers for the Barque Jane, above n 40. The ship was arrested on 7 October 1841 (Naylors' bond) and 9 October 1841 (Wade bond): Naylor \& Ors v "Jane" Warrant to Arrest Ship and Cargo, Case Papers for the Jane, above n 40; John Wade by John Jones $v$ The Ship Jane \& freight, Warrant of Arrest in a 
in their favour. ${ }^{77}$ However, ultimately the Naylors' bond was ranked in priority behind that of the second bond obtained in Wellington. Under admiralty law, later bonds took priority over earlier bonds. ${ }^{78}$ The "Jane" was put up for auction under court order. ${ }^{79}$ The sale of the ship (ultimately to John Jones, agent for John Wade), fetched $£ 680$, reduced to $£ 571.5 .4$ after costs, insufficient to discharge even the Wade bond. ${ }^{80}$ As Master, Stobo had bound not just the "Jane", but also himself and his heirs, he remained personally liable. We can presume, therefore, that the William Stobo declared insolvent in Sydney in November 1842 was one and the same. ${ }^{81}$

At trial it was more or less assumed that there was no institution through which Smith could have put the ship into suit. Chapman noted that Halswell was Deputy Vice-Admiral, but had no idea from when this jurisdiction had become available. ${ }^{82}$ Halswell was not appointed Deputy until March 1842, hearing cases late in that year in Admiralty, albeit without, as it turned out, the power to do so despite his appointment. ${ }^{83}$ However, by the time of Pharazyn II, the hearing for an arrest of judgment and re-trial, Chapman was of the opinion that vice-admiralty jurisdiction had been

Case of Bottomry, Case Papers for the Barque Jane, above n 40 These warrants were in addition to that for the unpaid seamen's wages.

77 Naylor Bros v Barque "Jane", Decree, 17 December 1841, Case Papers for the Barque Jane, above n 40.

78 For priories of bonds see Rhadamanthe, above $\mathrm{n} 49$.

79 See public notice by the Marshal of the Vice-Admiralty Court in The Sydney Gazette and New South Wales Advertiser (Sydney, 15 January 1842) at 3. The "Jane" was put up for auction on 24 January, failed to raise a sufficient bid, and was again put up for sale on 15 February: Affidavit of Alfred Elyard, Marshall of the Vice-Admiralty Court, Case Papers for the Barque Jane, above n 40.

80 Marshall's Account, Case Papers for the Barque Jane, above n 40; Ship "Jane", William Stobo, Savings Bank Receipt, Case Papers for the Barque Jane, above n 40. In Pharazyn I Stobo stated that the sale price was $£ 695$, but this appears to be incorrect: Chapman "Notebook: Civil Trials 1", above n 4, at 90.

81 See call for creditors to present claims against William Stobo, insolvent, in the New South Wales Government Gazette (29 November 1842) at 1779.

82 Jones $v$ Smith, above $\mathrm{n} 4$.

83 Halwell was created his Deputy "with full power to take cognizance of and proceed in all matters, and to hear and determine ... all cases, civil and maritime": New Zealand Government Gazette (23 March 1842) at 77. Under this authority Halswell heard several cases in Admiralty. He was later reprimanded, and informed that as no instance court had been established he did not have authority to act in Admiralty: Colonial Secretary to Halswell, 15 March 1843, AGCO 8336 IA4/258, 43/8, at 69. For his decisions see Morris Mahoney, Vice-Admiralty Court Wellington, 8 November 1842 per Halswell J, (mutiny, convicted of common assault), reported in the New Zealand Colonist and Port Nicholson Advertiser (Wellington, 11 November 1842) at 2. See also In the Matter of the Schooner Ganet, Vice-Admiralty Court Wellington, 1 December 1842 per Halswell J, reported in the New Zealand Colonist and Port Nicholson Advertiser (Wellington, 6 December 1842) at 2; Fisher v Toohey, Jones v Toohey, Cadman v Toohey, Macarthy v Master of the Success, all heard in early December by Halswell J, reported in the New Zealand Gazette and Wellington Spectator (Wellington, 3 December 1842) at 2 (first three for wages, last for pilotage and settled out of court). 
available since mid-1841. Hobson was created Vice-Admiral on 27 August, ${ }^{84}$ although no Instance Court was established. ${ }^{85}$ Letters patent appeared to give Hobson some Admiralty jurisdiction. They empowered him to "take cognizance of and proceed in all cases civil and maritime ... to hear and determine the same according to the Reports, Statutes Laws Ordinances \& Customs actually observed". By Pharazyn II, Chapman had become aware of the possibility that the bond could have been put into suit in Auckland on the "Jane's" arrival on 27 August 1841. He noted that this fact had been ascertained from a "careful perusal of the Gazette". ${ }^{86}$ He went as far as to suggest that the "Jane" had "actually sailed as it were into the Lion's mouth. ... Wellington though the most populous and commercial town in the colony was only in contemplation of law an outport. The proper place to seek a court of V A was the capital." 87 However, given the problems of communication in an infant colony it seems doubtful whether Smith or Stobo could have been expected to know this. Further, given the reprimand suffered by Halswell in exercising jurisdiction without a Court of Instance, it is not clear that the bond could have been put into suit in front of Hobson. However, once put into admiralty in New South Wales the matter was relatively straightforward. In Dowling CJ's Admiralty notebook the matter of the "Jane" rated no more than a passing reference. ${ }^{88}$ Prosecuted at common law, however, the facts sat awkwardly with the law,

84 Letters Patent issued by the High Court of Admiralty on 13 March 1841: Captain William Hobson Appointment as Vice-Admiral of New Zealand, 13 March 1841, ANZ, AGCO IA9/3; proclaimed as of 27 August 1841 in the New Zealand Government Gazette (29 September 1841) at 71.

85 No admiralty jurisdiction was conferred by the original ordinance establishing the Supreme Court: Supreme Court Ordinance 18415 Vict No 1 (in any case later disallowed). In 1844 the Supreme Court was finally constituted an instance court by local ordinance: Supreme Court Ordinance 18447 Vict No 1, s 6. However, in 1846 this jurisdiction was repealed after Governor Grey was advised that the local legislature did not have the power to confer vice-admiralty jurisdiction, which could only be granted by Letters Patent: Supreme Court Amendment Ordinance 184610 Vict No 3, s 1; Stanley to George Grey, 13 August 1845 , Great Britain Parliamentary Papers 1846 (337) at 83 (also printed in the New Zealand Government Gazette (23 October 1846) at 82). Despite this, Chapman seems to have been under the belief that he still had this jurisdiction, writing to his father that he needed more texts on admiralty law "for I am a judge of the ViceAdmiralty Court": HS Chapman to H Chapman "Letters", vol 2, 1847-1848, ATL, qMS-0419, letter dated 5 June 1847 at 433 . He continued to exercise vice-admiralty jurisdiction, as did Martin CJ: see for example $R$ $v$ George Jefferson and John Jones, Vice-Admiralty Court Wellington, 2 March 1850 per Chapman J, reported in New Zealand Spectator and Cook's Strait Guardian (Wellington 6 March 1850) at 3 (piracy). In 1861 the judges themselves requested clarification from the Law Officers as to their authority to exercise admiralty jurisdiction, noting that cases had been heard, most likely without authority to do so: Supreme Court Judges (Arney CJ, Gresson and Johnston JJ), Memo 22 May 1861, enclosure in Despatch 80/1861, Gore Brown to Newcastle, 29 May 1861, TNA, CO209/162: 213-218; see also Paul David "The Jurisdiction that Never Was" (2001) NZLJ 372. Jurisdiction was finally conferred by the Vice-Admiralty Courts Act 1863 (UK).

86 Chapman "Notebook: Sittings in Banco", above n 4, at 89.

87 Ibid, at 90 .

88 James Dowling, "Notebooks: Vice-Admiralty and Equity, 1841", SRNSW, NRS 5872 [2/3440], Friday 31 December 1841 at 2; 15 February 1842 at 2 and 50 (both seamen's wages and bond). 
requiring the jury to make a difficult decision as to how Smith should have acted in the absence of a proper forum, or any knowledge that such a forum existed.

In his summing up to the Jury, Chapman $\mathrm{J}$ effectively repeated the choices given by counsel. Was it incumbent on the defendant to ascertain the value? Should the plaintiffs have offered it, and if so had they done so sufficiently in their various interviews with Smith? There had been much evidence given at trial as to value of the ship, but the question was did Smith know the value and did he reject it? In any case, was the absence of a Court of Vice-Admiralty sufficient to relieve him from his obligations? Chapman seemed to acknowledge that no good title could in any case have been given by Smith, but at the "same time the non-existence of a Court cut two ways, as it prevented any dispute about title arising out of the bond". ${ }^{89}$ The jury returned a verdict of $£ 390$ damages for Mrs Jones. Pursuant to seemingly almost identical decisions on the subsequent day the jury awarded Stobo $£ 130$, and the day after that Pharazyn received $£ 661,16 \mathrm{~s}$.

\section{$V$ PHARAZYN V SMITH II: HEARING FOR A RE-TRIAL AND SUPREME COURT PROCEDURE}

Several weeks after the trials, Smith, through his barristers Hart and Daniel Wakefield (who replaced Holroyd), applied to the Supreme Court for rules nisi, calling on the plaintiffs to show cause why the judgment should not be arrested and the issue amended or a new trial granted. The rules nisi hearing, therefore, effectively functioned as a first glance at whether there was enough on which to sustain a full argument before the court. After several days cogitation, Chapman J granted the rules, and the plaintiffs were back in court again several weeks later to show cause why the judgment should stand.

It is difficult to work out the exact basis on which Smith was arguing for arrest and retrial. Chapman noted that "the affidavits which have been filed in support of the rule contain a vast amount of allegations". ${ }^{90}$ In essence, however, it seemed that the key point alleged was that "the issue was defective in not raising the question whether Captain Stobo had the power to sell or transfer the ship".91 By this Wakefield meant the issue was whether the ship and securities could have been handed to Smith by Stobo, and whether Smith might lawfully and safely have taken them. ${ }^{92}$ Chapman $\mathrm{J}$ interpreted this to be an argument that there was a latent defect on the record so as to warrant an arrest and new trial. ${ }^{93}$ The latent defect was the failure to raise the question of power or title at trial. On behalf of Pharazyn, Hanson disputed this, effectively arguing that the

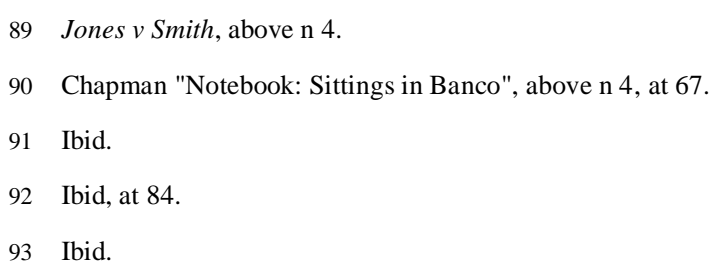


defendant had had all the opportunity he required at trial to raise these questions. The plaintiffs had done what they needed to support the action. If the defence was not adequate then there was nothing that could now be done. ${ }^{94}$ In response, Wakefield took, what Chapman J described as a "course which is certainly unprecedented". He simply folded. Rather than continue with his request to arrest judgment, Wakefield "abandoned the terms of the motion altogether, he admitted almost all that had been argued against the Rule, he admitted that he had no grounds for a new trial, and appealing to the equity jurisdiction of the Court, he asked for a bill of review as the only proceeding which would now meet the justice of the case". ${ }^{95}$

Why equity? And why a bill of review? After all, a bill of review in equity was simply analogous to a rule for a new trial at law - that rule which Wakefield had just abandoned, admitting that it would not succeed. In any case, a bill of review could not, as Chapman J pointed out, disturb proceedings at law. ${ }^{96}$ This could have ended matters. However, Chapman J determined to hand down a full judgment, addressing all points raised by counsel for Pharazyn. Forced to face that mistakes had been made at trial, Wakefield appealed not to the strict law of equity, but to equity as some generalised form of justice. It was not that the strict rules of equity could be called upon now, but that they should have been at trial, and it was the fault of the court that they had not been. Thus, equity in some generalised capacity should now give relief and it should do this by way of a bill of review. The mistake at trial alleged by Wakefield and Hart was that the defendant should have requested a bill of interpleader in equity. In effect this was an argument that the wrong party was sued - it should have been Naylor Bros \& Co, not Smith. Smith was a mere stakeholder who had never had the power to sell the ship and return the securities. It was the fault of the Court that this had occurred because it was the responsibility of the judge to make up the issue - in other words to determine the issues for trial - and the judge had not suggested a bill of interpleader. Recourse to equity was based, therefore, as Chapman put it, on "the alleged neglect of the judge to assume the function of legal advisor". 97

A bill of interpleader (an equitable suit) could be used to join parties where the person against whom the action was being taken was effectively a stakeholder. Where the party, here Smith, has no interest in personal property, but is merely the holder of a stake contested equally by two claimants, and fears he may suffer injury from the conflicting claims, he may join the alleged owner. This would have allowed the issue of who actually held title to be raised. Bills of interpleader were originally only available in equity. Only equity had the ability to bring third parties before the court and investigate their respective claims. The common law did not pay regard to third parties.

\footnotetext{
94 Ibid, at 54.

95 Ibid, at 68.

96 Ibid, at 72.

97 Ibid, at 77.
} 
Therefore the appropriate course for someone in Smith's position was to file a bill in equity to compel the parties to interplead at law. However, in 1831, the ability to interplead at law without recourse to equity was provided under the provisions of the Interpleader Act $1831 .{ }^{98}$ This act also provided a reasonably simple procedure for joining the third party. In certain actions, including trover, the defendant could bring the subject matter into court and call upon the judge to make an order calling the third party (the alleged legal owner) to appear, and until they did so to stay the proceedings. Once the third party was in court they could be joined to the action and the merits of the relative claims determined summarily. Thus, had he interpleaded, Smith could have effectively insulated himself from the damages claim, leaving the plaintiffs and Naylors to contest who had the better right.

The failure to suggest a bill of interpleader when making up the issue had resulted according to Wakefield, in his client suffering an injustice, and he argued therefore that in all conscience the court ought to remedy that injustice. He alleged that "[i]f an injustice has been committed I say by the court - but at all counts somewhere. It was a case for a Court of Equity which was overlooked by the legal adviser of the Deft. and by the judge who made up the issue. Judge ought to have said: 'this is a case for Equity."'99 Hart, who reappeared for Smith, and who had represented Smith at trial, seemed desperate to apportion blame elsewhere: "If the judge who made up the issue had shown only a hint we should have adopted it". 100

At heart, therefore, of Pharazyn II is the question of whose responsibility it was to determine the proper action to be brought, and the course of litigation, at the time of making up the issue. Wakefield argued that a case such as this could not arise in England. There was not, he admitted, a "ground for arrest of judgment according to the practice of England". But, he argued, the case would be different in New Zealand. English practice, he argued, could not apply. In New Zealand: "the judge presides over the issue and in fact makes up the pleadings which are the record and for which the court in answerable". Thus, English practice could not apply "for there's no court in England with such powers. There is indeed no court like this in any part of the world". ${ }^{101}$ Thus, according to Wakefield, in England ... the pleadings are managed by a learned body of men [but] here the court presides over pleadings and is responsible for them \& is bound to amend". ${ }^{102}$ It was, therefore, the fault of the court that the central issue had not been properly raised: "the issue in this case is calculated to do wrong $\&$ the court will not suffer wrong to be done by its acts". ${ }^{103}$ The Judge's

98 Interpleader Act $18311 \& 2$ Will IV c 58 (UK).

99 Chapman "Notebook: Sittings in Banco", above n 4, at 58.

100 Ibid, at 62 .

101 Ibid, at 58 .

102 Rules nisi hearing, ibid, at 39.

103 Ibid. 
failure was, according to counsel, compounded by the Supreme Court Rules themselves. They were defective. Equity's intervention therefore was also justified on the basis that "the court itself [was] responsible on the ground that its rules do not point out the proper course". Defending himself in the local newspaper against Wakefield's allegations of incompetence, Holroyd maintained that under the "peculiar rules" adopted for the new Supreme Court "it appeared impossible to obtain that relief which, under a different system, the defendant might have obtained". ${ }^{104}$ Hart made a similar allegation when arguing for the arrest of judgment and re-hearing in Pharazyn II. ${ }^{105}$

To what extent, however, was the judge before whom the issue was made up at least obliged to provide some guidance? As noted above, Martin suggested in his "Report" that the judges did have some responsibility in this matter. Indeed the Rules themselves required judges to take note of any defences available at law or in equity. In Pharazyn Chapman J did not deny this. However, it was certainly not entirely the responsibility of judges to determine the course of litigation. He pointed out that in this instance the Judge could not be expected to suggest other options if they were founded in a state of affairs or facts that he could not know. He confirmed that it is "no part of the judge's duty to suggest an alternative course, where there is nothing on the face of the proceedings to show that the course adopted was wrong". ${ }^{106}$ In this case, suggestion of recourse to equity (for reasons described below) could only have been ascertained by reference to facts unknown to the judge. He went as far as to suggest that "it would savour of presumption" to suggest any course of action where the defendant "appeared by counsel, with more knowledge of the circumstances than the learned judge could possibly possess". ${ }^{107}$ Nevertheless, his judgment suggests that if a judge were in possession of all the facts he might be expected to contribute to the isolation of legal issues and consequent formulation of the issues.

Interestingly, Chapman's use of the term "judge" in the third person throughout may further suggest that Chapman did not make up the issue himself. Pharazyn had first come on for hearing in the previous October, before Martin CJ. It was then postponed until the following session, which was April 1844 when the case was finally heard. ${ }^{108}$ To complicate matters further, as Martin himself explained in his report on the judicial establishment in the colonies in 1843, outside Auckland the issue was made up for all Supreme Court actions by the local judge of the County

104 New Zealand Gazette and Wellington Spectator (Wellington, 22 May 1844) at 3; New Zealand Gazette and Wellington Spectator (Wellington, 24 May 1844) at 3.

105 Chapman Rules nisi hearing "Notebook: Sittings in Banco", above n 4, at 63.

106 Chapman "Notebook: Sittings in Banco", above n 4, at 74.

107 Ibid, at 76.

108 Pharazyn v Smith Supreme Court Wellington per Martin CJ, 3 October 1843, reported in the New Zealand Gazette and Wellington Spectator (Wellington, 25 October 1843) at 3. 
Court, in this case Edmund Storr Halswell, the man who had been appointed Deputy Vice-Admiral by Hobson. ${ }^{109}$ Whether the issue was again made up the following April is unknown.

In any case, Chapman refuted that the Judge ought to have told them to interplead. The Judge, according to Chapman, did not know that Naylors were not providing the funds for the litigation, nor that "the Defendt. as agent for Naylor \& Co did not voluntarily and advisedly put themselves in his position". After all, it was, according to Chapman, reasonably common in mercantile matters not to interplead because it made litigation quicker and cheaper. ${ }^{110}$ If the failure to interplead was not the fault of the Judge, as Chapman stated, was it the fault of "peculiar rules" of the court which did not provide guidance? In fact, it was possible to interplead under both the 1843 and 1844 Rules. Not only was interpleading possible, but the rule was drafted to allow interpleading in a wider range of circumstances than would have necessarily been permissible in England at the time. Rule 71 of the 1844 Rules ( $\mathrm{r} 70$ of the 1843 Rules) provided that the provisions of the Interpleader Act 1831 should apply to claims whether legal or equitable. As Chapman noted, Martin's rule removed lingering doubts held in England as to whether the Interpleader Act 1831 could apply to equitable claims. ${ }^{111} \mathrm{He}$ went on to say that "in clearing our practice of these doubts my brother Martin has certainly conferred a boon on the public". ${ }^{112}$ Interpleading had certainly been possible but, as in England, it would have had to occur after the declaration and before the plea. There was no general equitable jurisdiction to grant a bill of review after the trial and review the matter simply because the action went against the defendant. As Chapman concluded "I would not have dwelled so long on this part of the subject but the conduct of the judge was impugned[,] an attempt was made to cast a responsibility on the court which does not belong to it and which it now disclaims, the scope of its rules was misunderstood, and its equitable \& legal jurisdiction were confounded". ${ }^{113}$ To perhaps ram home the point, Chapman noted that the "remedy [of interpleader] is sufficiently explained in the books of practice in use here as well as at home. The whole subject matter is well laid down in a work which I have seen in common use in this court ... that most elaborate and comprehensive work Chitty's General Practice of Law."114

Chapman J did not deny that the defendant had suffered a loss, but it was "what the old lawyers would have called damnum absque injuria, ie loss without any legal wrong". ${ }^{115}$ But it was not, in

109 Martin "Report", above n 5, at 447-448.

110 Chapman "Notebook: Sittings in Banco, above n 4, at 75-76.

111 Ibid, at 79-80. For uncertainty at the time in England see Putney $v$ Tring (1839) 5 M \& W 425, 151 ER 180 (Ex)

112 "Notebook", ibid, at 80 .

113 Ibid, at 81.

114 Ibid, at 78 .

115 Ibid, at 98. 
any case, as a result of the rules of court. The defendant had chosen his course at trial and had failed to apply for a bill at the appropriate time. Further, the plaintiffs had averred all they needed to sustain their actions, including the facts which the plea put in issue. It was clear, it was intelligent, and if they did not "embrace all the defendant now wishes", it was effectively too late. ${ }^{116}$ Nor, even in a court with dual jurisdiction, could equity save the plaintiff: "It is I know" stated Chapman "a vulgar error that a court of equity has a sort of roving discretion to revise and control legal proceedings; but whether what we call equity or what an American writer has more properly called The Law of Equity be administered by a distinct court or by the ordinary legal tribunal, it is as much in the dominion of strict rules, as what we call law, and those rules forbid the court to entertain the learned counsel's proposal." 117 Chapman further reminded counsel that rules are not designed to define specific rights or remedies. They instruct how to get a rule, but not on what every rule should be based. In the new colony, they were designed to be "even more limited in their object. They speak only where an alteration has been made in the practice of the courts at Westminster and where they are silent, English practice prevails."118

There was, however, a clear relationship between the role of the judges in making up the issue and the general constitution of the rules. This again suggests that judges were intended to take some active role in determining issues. In their 1854 Report, Chapman and Martin noted that one consequence of the return of pleadings to the hands of the barristers was that the "Rules of Court will require to be filled up in detail, as to become more complete and directory". ${ }^{119}$ The rules certainly filled up in detail, going from a modest 75 in 1844 to a compendious 543 in $1856 .{ }^{120}$ It seems, however, that they did not intend to entirely remove the participation of judges. They went on to state that "[t]he great advantages which have been observed to arise from the personal conference of the parties or their agents, in the presence of a judge, before the issues are finally settled, ought, we think, under any system, to be carefully retained". ${ }^{121}$ As a result, Martin and Chapman explicitly adopted the procedure of the Court of Session in Scotland as to the framing and settling of issues. ${ }^{122}$ In the new version, the parties were to draft the issues, later confirming them

\author{
116 Ibid, at 83 . \\ 117 Ibid, at 72 . \\ 118 Ibid. \\ 119 [Martin, Chapman] Reports of the Commissioners, above n 15, at 6. \\ 120 An Act for Regulating the Procedure of the Supreme Court 185619 \& 20 Vict No 15; Rules of the Supreme \\ Court, Annex A to Reports of the Commissioners, ibid. \\ 121 Ibid, at 6 . \\ 122 Ibid, at 93.
}


with a judge who settled and approved them. ${ }^{123}$ In this aspect alone, the rules were much more detailed and directive.

Despite his uncertainty in Pharazyn I as to power of sale, it seems that by Pharazyn II Chapman had determined that Smith could have effected a sale. He stated that it was not justified "to regard the deft. as a trespasser whom a mere police magistrate could have ousted". He was "the proper guardian of the ship (the Legal title was in the defandt, at the time the owner had no more than a sort of equity of Redemption. A Court of A. might no doubt have defeated that title by declaring the bond void, but that decree must also, have liberated the securities)". 124

It seems fairly clear where Chapman slated the failures at trial. Days after Pharazyn, Strobo and Jones, Chapman wrote to his father of the cases, noting that Holroyd had been involved and that he "does his work badly". ${ }^{125} \mathrm{He}$ further noted that "[h]e had three causes that would have made any man who was master of his business, but has so mismanaged them that they will act as a quietus". ${ }^{126}$ Chapman wrote home to his father in May 1844 that he had "just given a very elaborate judgment in a motion for a new trial". He reported that "the Defendant is not satisfied with the judgment or with the verdict of the jury and it is to be appealed to the Privy Council. I am pretty sure the judgment will be affirmed". ${ }^{127}$ As far as can be determined, no such appeal took place.

\section{CONCLUDING COMMENTS: THE 'CIRCUMSTANCES OF THE COLONY'}

One of the notable features of the Crown colony period was the lack of specific judicial determinations on the adoption of English law and its adaption to the new colony. ${ }^{128}$ Unlike the Forbes court in New South Wales, which heard a number of important decisions on reception of English law and its appropriateness for the circumstances of the colony, particularly between

1231856 Rules, above n 120, rr 125-133

124 Chapman "Notebook: Sittings in Banco", above n 4, at 88.

125 Chapman "Letters", above n 11, letter dated 26 April 1844 at 89.

126 Ibid. Chapman had a pre-existing personal relationship with Holroyd. They had been on the Northern Circuit in England together, and Holroyd had lodged with Chapman in Pontefract: ibid, letter dated February 101844 at 74. It seems clear they had some history. In the specific context of Pharazyn Chapman writes to his father that "I should have quietly watched my opportunity and should have tripped him up in Court rolled him in the mud and effectually cut his claws": ibid, letter dated 26 April 1844 at 87. Holroyd left for India about a year later under the cloud of a scandal involving allegations of cruely to his daughter and inappropriate relations with the governess/housekeeper. He got no further than Sydney. There he became a well-known barrister, Master in Equity of the Supreme Court in Equity, member of the New South Wales Legislative Council and even briefly an acting judge of the Supreme Court.

127 Ibid, letter dated 13 May 1844 at 97.

128 However, on the allied matter of the recognition of commercial custom in the colony see the article by Stuart Anderson in this volume. 
inception of the court and $1836,{ }^{129}$ such cases were notably absent in the early period in New Zealand. Rather, as Damen Ward points out in his article in this collection, much of the adaption of English law in the Crown Colony period occurred by ordinance.

In 1842 James Stephen praised the early legislative efforts of the colony, a batch of nineteen ordinances on a wide range of matters. Stephen stated that he was not in favour of legislative "overactivity", but nor was he particularly in favour of leaving matters in the hands of the judges. ${ }^{130}$ In this instance, he specifically noted that "in the infancy of a colony the choice must be made between the adoption of an old and inapplicable code, or of a new and immature code". He noted that "both are evils, but it is much safer to begin with a rigorous effort to lay the foundations of law on a right and durable basis". ${ }^{131}$ While Stephen conceded that all the ordinances might eventually need amendment, they constituted a far better basis than if the old law had been followed in adopting the Law of England "so far as it might be found applicable to the circumstances of the colony". ${ }^{132}$ Stephen thought that the first nineteen ordinances "indicate[d] a very remarkable degree of learning, foresight and practical ability". ${ }^{133}$ Swainson, the man who drafted most of those ordinances, had, as indicated at the outset, most likely aided the drafting the first Rules of the Supreme Court, and probably consulted with Martin on subsequent laws. It would be unusual for an Attorney-General in the period not to take advantage of the advice of the Chief Justice, especially of one who was in fact a close neighbour and friend.

While Martin CJ, and later Chapman J, had a limited role though judicial determination in adapting law to local circumstance, their court rules represented a significant attempt to do just that, although there is no indication that they would have been shy in taking on the task through the courts had appropriate cases come before them. However, they did not. In his 1843 Report on the Courts and the Judicial Establishment, Martin specifically defended his abandonment of English procedure, in favour of judges "making up the issue", on the grounds of the necessity to adapt court procedure to the local circumstances of the colony. He contrasted the circumstances of the colony with those of England. In England the judicial machinery centred on London: "through the whole of the pleadings constant reference is made to London". In New Zealand, "a similar mode of proceeding is impossible". ${ }^{134}$ In particular he pointed to the problems caused by the distance of the

129 For example, on usury laws, liability of sheriffs, the felon attaint rule, and even whether an emu could be stolen: see Bruce Kercher "Judges and the Application of Imperial law in Eastern Australia, 1788-1836: Resistance and Reception" in David Lemmings (ed) The British and Their Laws in the Eighteenth Century (The Boydell Press, Woodbridge, 2005).

130 Memo Stephen to Stanley (29 September 1842) TNA, CO209/14, fol 361.

131 Ibid, fol 360.

132 Ibid, fol 361.

133 Ibid, fol 361.

134 Martin "Report", above n 5, at 442-443. 
settlements from each other, "and the want of facilities of communication". Pharazyn $v$ Smith itself highlights this point. Even once Hobson was appointed Vice-Admiral, it took months for the patent to reach New Zealand, and more time for news of this to reach Wellington: all too late for our plaintiffs.

In New Zealand legal centralisation was of a different nature to that of England or even some other colonies: "[a] British colony had generally consisted for some years from its foundation of a single town with a small settler territory lying around it and easily accessible for it. Centralisation in matters of law has been as easy as it was natural." That was not the case in New Zealand with its multiple and multiplying settlements. Further, at the time Martin wrote this he was the sole judge in the colony, with circuit courts only taking place twice per year. ${ }^{135}$ Martin thought, though, that this might come to be seen in the longer term as a "circumstance far from unfavourable to the interests of the Country". ${ }^{136}$ Martin's zeal for "provid[ing] for the people of the land a simpler and sounder system of procedure", ${ }^{137}$ was well-matched with Chapman's Benthamite tendencies towards codification and his desire to use law reform to make his mark. For both, locally appropriate court procedure was to remain a focus of their endeavours throughout the 1840s and first half of the 1850s. Through all of it, making up the issue remained in some form a central plank of New Zealand procedure and pleadings.

135 Ibid, at 442.

136 Ibid, at 445 .

137 Martin "Martin Papers 1851", Martin to Chapman letter dated 31 March 1851, above n 15, unpaginated. 